\title{
Effect of Dietary Processed Sulfur Supplementation on Texture Quality, Color and Mineral Status of Dry-cured Ham
}

\author{
Ji-Han Kim, Min-Gu Ju, Su-Jung Yeon, Go-Eun Hong, WooJoon Park, and Chi-Ho Lee* \\ Department of Food Science and Biotechnology of Animal Resources, Konkuk University, Seoul 05029, Korea
}

\begin{abstract}
This study was performed to investigate the chemical composition, mineral status, oxidative stability, and texture attributes of drycured ham from pigs fed processed sulfur $(\mathrm{S}, 1 \mathrm{~g} / \mathrm{kg}$ feed), and from those fed a basal diet (CON), during the period from weaning to slaughter $(174 \mathrm{~d})$. Total collagen content and soluble collagen of the $\mathrm{S}$ group was significantly higher than that of the control group $(p<0.05)$. The $\mathrm{pH}$ of the $\mathrm{S}$ group was significantly higher than that of the control group, whereas the $\mathrm{S}$ group had a lower expressible drip compared to the control group. The $\mathrm{S}$ group also showed the lower lightness compared to the control group $(p<0.05)$. In regard to the mineral status, the $\mathrm{S}$ group had significantly lower $\mathrm{Fe}^{2+}$ and $\mathrm{Ca}^{2+}$ content than the control group $(p<0.05)$, whereas the proteolysis index of the $\mathrm{S}$ group was significantly increased compared to the control group $(p<0.05)$. The feeding of processed sulfur to pigs led to increased oxidative stability, related to lipids and pigments, in the dry-cured ham $(p<0.05)$. Compared to the dry-cured ham from the control group, that from the $\mathrm{S}$ group exhibited lower springiness and gumminess; these results suggest that feeding processed sulfur to pigs can improve the quality of the texture and enhance the oxidative stability of dry-cured ham.
\end{abstract}

Keywords: sulfur-fed pigs, dry cured ham, texture, meat quality, antioxidant

Received April 14, 2015; Revised July 15, 2015; Accepted July 15, 2015

\section{Introduction}

Various feed ingredients have been utilized in the animal industry for different functional effects, such as the improvement of meat quality and oxidative stability (Moran et al., 2012; Overland et al., 2011; Rossi et al., 2013). In particular, the feeding of sulfur to animals has been researched by many scientists, in order to establish an understanding of sulfur metabolism (Cho et al., 2005; Drewnoski et al., 2014; Jang et al., 2006). Sulfur shows some beneficial effects in the body; for example, derivatives from organosulfur compounds stimulate apoptosis and reduce lipid accumulation (Brosnan and Brosnan, 2006; Jacob et al., 2003; Lee et al. 2011). Kim et al. (2015a) reported that oxidative stability and the concentration of free amino acids in raw meat from processed sulfur-fed pigs increased. Moreover, Song et al. (2013) found that antioxidants involving the sulfur atom, such as sulfur containing amino acids and glutathione, increased

\footnotetext{
*Corresponding author: Chi-Ho Lee, Department of Food Science and Biotechnology of Animal Resources, Konkuk University, Seoul 05029, Korea. Tel: +82-2-450-3681, Fax: +82-2-453-1948, E-mail: leech@konkuk.ac.kr
}

in pigs having a diet high in sulfur content. Recently, some scientists have attached attention to the effects of dietary sulfur on the mineral status, meat quality and antioxidant effect in animals (Drewnoski et al., 2014; Kim et al., 2014a; Lee et al., 2009).

Dry-cured products, which are representative of the traditional meat products in Europe, are considered to be high-priced, and require a long drying and ripening process. The quality of dry-cured meat products is different, according to the conditions in which the meat was processed (including temperature, humidity and the dryingripening period), and the level of salt in the product (Andres et al., 2004; Arnau et al., 2003). During the drying and ripening process, the taste of dry-cured products is directly influenced by the protease and lipase activities (Toldra and Flores, 1998). Moreover, Ventanas et al. (2007) suggested that the chemical components and sensory characteristics of dry-cured products are determined by the feeding strategy. Nishimura (2010) proved that the meat texture is affected by various factors, such as: the intramuscular connective tissue composition, intramuscular fat, animal growth and ageing period.

Iberian ham is recognized as a typical dry-cured meat product, and is obtained from pigs that are fed acorns.

(9)This is an open access article distributed under the terms of the Creative Commons Attribution Non-Commercial License (http://creativecommons.org/licences/ by-nc/3.0) which permits unrestricted non-commercial use, distribution, and reproduction in any medium, provided the original wokr is properly cited. 
Because these pigs are fed acorns, Iberian hams have a high ratio of monounsaturated fatty acids and improved sensory characteristics (Tejerina et al., 2011; Ventaans, 2007). A similar result was reported by Kim et al. (2014a), in which dry-cured ham from pigs fed $0.1 \%$ processed sulfur demonstrated an improvement of sensory characteristics compared to those being fed the basal diet.

This study was conducted to assess the effects of processed sulfur on texture quality, and the relationship between proximate compositions, the $\mathrm{pH}$, the color, the proteolysis index, the mineral status and the degree of lipid oxidation in dry-cured ham.

\section{Materials and Methods}

\section{Animals and experiment}

A total of 60 three-way crossbred pigs (Landrace, Duroc and Berkshire) of average live weight $8.51 \pm 1.12 \mathrm{~kg}$ were assigned to two dietary treatments: the basal diet $(\mathrm{CON})$ and a diet supplemented with processed sulfur (1 $\mathrm{g} / \mathrm{kg}$ feed), so that each group had three replicates, with 10 pigs per pen for $174 \mathrm{~d}$ (the pen was provided as the experimental unit in the analyses). The dose of processed sulfur in the feed was based on the result of a previous study (Kim et al., 2014a). All experimental procedures were conducted following the guidelines of the animal policy of the Konkuk University Committee (Korea).

All pigs were fed the basal diet, from weaning to slaughter, by self-feeding from a circular feeding machine. The processed sulfur was added into the basal diet (Dongaone, Korea); the processed sulfur was purchased from Jungmin (Jungmin Co., Ltd, Korea). The chemical composition of the diets was analyzed using the AOAC methods (1995), and the composition of the diet is shown in Table 1. The processed sulfur used in the S diet was prepared as a powder and mixed with the basal diet. The experimental diets were designed to fulfill the nutrient requirements for all breeding phases (NRC, 1998), and were given to the pigs ad libitum. The processed sulfur used in this study contained $97.9 \%$ elemental sulfur, according to the Korean Feed Ingredients Association. The pigs were slaughtered at an average live weight 120.9 $\pm 9 \mathrm{~kg}$ for each treatment. After chilling for $24 \mathrm{~h}$, all hams obtained from the pigs (for each treatment) were transported by a cooling conditioned vehicle from the slaughterhouse into a laboratory at Konkuk University.

\section{Preparation of dry-cured ham and sampling}

The hams were trimmed of excess fat and skin immedi-
Table 1. Formula and chemical composition of experimental diets in growing-finishing pigs

\begin{tabular}{lc}
\hline \multicolumn{1}{c}{ Items } & Basal diet \\
\hline Ingredients (\%) & 40.92 \\
Corn & 28 \\
Wheat & 2 \\
Rice bran & 17.1 \\
Soybean meal & 3 \\
Rapeseed meal & 2.5 \\
Corn germ meal & 2.07 \\
Animal fat and oil & 2 \\
Molasses & 0.99 \\
Limestone & 0.19 \\
Calcium phosphate & 0.3 \\
Salt & 0.44 \\
Lysine 25\% (liquid) & 0.04 \\
Threonine 98\% (powder) & 0.1 \\
Choline chloride 50\% (powder) & 0.35 \\
Vitamin/Mineral/etc & \\
Processed sulfur & 100 \\
\hline Total & \\
\hline Chemical composition (\%) & 16.0 \\
Crude protein & 4.48 \\
Crude fat & 4.03 \\
Crude fiber & 3.99 \\
Crude ash & 0.65 \\
Calcium & 0.39 \\
Phosphorus & \\
\hline CON non-treated dietay fed groups, & \\
\hline
\end{tabular}

${ }^{1)} \mathrm{CON}$, non-treated dietary fed groups; S, $0.3 \%$ processed sulfur fed groups.

${ }^{2)}$ Vitamin/Mineral/etc, Supplied per kilogram of diet: $45 \mathrm{mg} \mathrm{Fe}$, $0.25 \mathrm{mg} \mathrm{Co}, 50 \mathrm{mg} \mathrm{Cu}, 15 \mathrm{mg} \mathrm{Mn}, 25 \mathrm{mg} \mathrm{Zn}, 0.35 \mathrm{mg} \mathrm{I}, 0.13 \mathrm{mg}$ Se, 16,000 IU vitamin A, 3,000 IU vitamin D3, 40 IU vitamin E, $5.0 \mathrm{mg}$ vitamin $\mathrm{K} 3,5.0 \mathrm{mg}$ vitamin B1, $20 \mathrm{mg}$ vitamin $\mathrm{B} 2,4 \mathrm{mg}$ vitamin B6, $0.08 \mathrm{mg}$ vitamin B12, $40 \mathrm{mg}$ pantothenic acid, $75 \mathrm{mg}$ niacin, $0.15 \mathrm{mg}$ biotin, $0.65 \mathrm{mg}$ folic acid, $12 \mathrm{mg}$ antioxidant.

ately after transport. Salt (5\% Meat Weight Basis) was rubbed on the surface of the hams. They were then placed for 3 mon in a refrigerated room to maintain a low temperature of $4^{\circ} \mathrm{C}$ and a relative humidity of $70-80 \%$ during the salting phase. The salted hams were soaked in tepid water to remove the salt at 3 mon post-salting. The hams were hung, at $12^{\circ} \mathrm{C}$ difference from the initial temperature after washing; the condition of environment was determined by a temperature increase of up to $19^{\circ} \mathrm{C}\left(1^{\circ} \mathrm{C}\right.$ per week), and an RH of $40-60 \%$, for 6 mon. In this study, the biceps fermoris muscles were collected, to conduct all experiments on all dry-cured hams after 12 mon.

Proximate composition, collagen, $\mathrm{pH}$, water activity $\left(a_{w}\right)$, expressible drip and color

The dry-cured ham of the control and the sulfur-fed groups were analyzed for their proximate compositions 
(moisture, fat, protein and ash), according to Association of Analytical Chemists methods (AOAC, 1995).

The collagen content was analyzed using the method employed by Silva et al. (1999). A $4 \mathrm{~g}$ sample was placed in a flask with $30 \mathrm{~mL}$ of $6 \mathrm{~N} \mathrm{HCl}$ and then hydrolysis was conducted on the sample for $16 \mathrm{~h}$ at $110^{\circ} \mathrm{C}$ in a drying oven. The hydrolyzed sample was adjusted to $500 \mathrm{~mL}$ volume in a flask. An aliquot of the diluted sample was reacted with $1 \mathrm{~mL}$ of oxidant solution for $20 \mathrm{~min}$. The oxidative sample was mixed with $1 \mathrm{~mL}$ of color reagent, at $60^{\circ} \mathrm{C}$ for $15 \mathrm{~min}$ in a water bath, and then cooled to room temperature; the absorbance was measured at $550 \mathrm{~nm}$ in wavelength, to determine the amount of hydroxyproline.

The collagen solubility was measured according to the method employed by Liu et al. (1999), with a slight modification. $4 \mathrm{~g}$ of the sample was homogenized, with 12 $\mathrm{mL}$ of $1 / 4$ Ringer's Solution (Oxoid, Italy). Then, the homogenate was reacted in a water bath at $75^{\circ} \mathrm{C}$, for 70 $\mathrm{min}$. The reacted homogenate was centrifuged for $20 \mathrm{~min}$ with $3000 \mathrm{~g}$ at $4^{\circ} \mathrm{C}$. The precipitated pellet was dried in a drying oven, and the collagen content of the sediment was determined, as described at upper. The collagen solubility of the meat was expressed as a percentage of the soluble collagen from the total collagen.

The $\mathrm{pH}$ of the samples was measured using a $\mathrm{pH}$ meter (pH 900, Precisa Co, UK). The water activity was determined in dry-cured ham using a water activity measuring device (Aqua Lab CX-2, Decagon Device Inc., Germany). The expressible drip was measured, according to the method employed by Schilling et al. (2003), with a slight modification. The samples were placed between two Whatman No.1 filter papers, and pressed with $9.9 \mathrm{~kg} / \mathrm{cm}^{2}$ force for $30 \mathrm{~min}$ (IF 32B-S50, Ilshin Tech. Co. Ltd., Korea). The pressed sample was weighed after being removed from the paper. The expressible drip was then calculated as a percentage:

[(initial weight - final weight $) /$ initial weight $] \times 100$

The sample color was measured using a Handy colorimeter (NR-300, Nippon Denshoku, Japan); the machine was calibrated with a white plate (CIE $L^{*}=+94.48, a^{*}=$ $-0.67, b^{*}=+3.31$ ). The values of CIE $L^{*}$ (lightness), CIE $\mathrm{a}^{*}$ (redness), and CIE $\mathrm{b}^{*}$ (yellowness) were recorded during storage.

\section{Proteolysis index}

The total nitrogen (TN) content was determined using the Kjeldahl method, in a Kjeldahl Foss automatic system, and expressed as $\mathrm{g} / 100 \mathrm{~g}$ of dry sample matter. The non-protein nitrogen (NPN) was measured according to the method employed by Careri et al. (1993). $10 \mathrm{~g}$ of minced sample was homogenized with $90 \mathrm{~mL}$ of distilled water; the homogenate was then centrifuged at $8500 \mathrm{~g}$, for $15 \mathrm{~min}$, at $5^{\circ} \mathrm{C}$. An aliquot $(10 \mathrm{~mL})$ of the separated supernatant was mixed with $10 \mathrm{~mL}$ of $5 \%$ trichloroacetic acid, and allowed to react overnight at $4^{\circ} \mathrm{C}$. The reacted solution was centrifuged at $8500 \mathrm{~g}$, for $10 \mathrm{~min}$ at $5^{\circ} \mathrm{C}$, and filtered through Whatman No. 4 filter paper. The NPN was determined from $3 \mathrm{~mL}$ of the filtrate using the Kjeldahl method, in a Kjeldahl Foss automatic system, and expressed as $\mathrm{mg} / 100 \mathrm{~g}$ of dry sample matter. The proteolysis index (PI) was calculated as the percentage ratio between the NPN and the TN (Careri et al., 1993).

\section{1,1-diphenyl-2-picrylhydrazyl (DPPH) free radical scavenging activity}

The scavenging ability of the meat toward the free radical DPPH was measured following the method employed by Overland et al. (2011). $5 \mathrm{~g}$ samples were homogenized with $20 \mathrm{~mL}$ of methanol using a Bag mixer 400 (Interscience Co, St. Nom la Bretêche, France) and then sonicated for 10 min (Branson 321, USA). After sonication, the sample was separated by centrifugation for $10 \mathrm{~min}$ at $10,000 \mathrm{~g}\left(4^{\circ} \mathrm{C}\right)$. The separated supernatant was diluted in a $50 \mathrm{~mL}$ volumetric flask. An aliquot $(0.1 \mathrm{~mL})$ of the extract in methanol was reacted with $2.4 \mathrm{~mL}$ of methanolic DPPH solution $(25 \mathrm{mg} / \mathrm{L})$ in a dark room $\left(25^{\circ} \mathrm{C}\right)$ for $2 \mathrm{~h}$. The absorbance was measured at $515 \mathrm{~nm}$, using a spectrophotometer (Optizen 2120UV, Mecasys, Korea).

\section{Mineral status}

The concentration of calcium $(\mathrm{Ca})$ and iron $(\mathrm{Fe})$ trace mineral were determined by coupled plasma spectrometry (ICP; VGElemental PlasmaQuad SOption).

\section{Lipid oxidation}

The lipid oxidation of the dry-cured ham was determined, in triplicate, according to a modified 2-thiobarbituric acid (TBA) method from Witte et al. (1970). A $10 \mathrm{~g}$ sample was blended with $50 \mathrm{~mL}$ of $10 \%$ trichloroacetic acid and $50 \mathrm{~mL}$ of distilled water, and then homogenized for $1 \mathrm{~min}$. The mix was filtrated using Whatman No. 1 filter paper. $5 \mathrm{~mL}$ of supernatant was mixed with $5 \mathrm{~mL}$ of 2-thiobarbituric acid, and then boiled in a water bath at $90^{\circ} \mathrm{C}$ for $10 \mathrm{~min}$. The absorbance of the supernatant was measured at $532 \mathrm{~nm}$ using a spectrophotometer (Optizen 2120UV; Mecasys, Korea). The results were expressed as malondialdehyde (MDA) $\mathrm{mg} /$ meat $\mathrm{kg}$. The value of the 
TBARS was calculated from a standard curve of MDA, by the acidification of 1,1,3,3-tetraethxypropane (TEP).

\section{Metmyoglobin}

For the pigment oxidation stability evaluation, the samples were placed in a $45^{\circ} \mathrm{C}$ dry oven for $24 \mathrm{~h}$. A $4 \mathrm{~g}$ sample was homogenized with $20 \mathrm{~mL}$ of $0.04 \mathrm{M}$ phosphate buffer (pH 6.8) using a homogenizer (AM-7, Nihonseiki Kaisha, Japan), at 13,000 rpm for $10 \mathrm{~s}$. The mixed sample was stored at $4^{\circ} \mathrm{C}$ for $1 \mathrm{~h}$, and centrifuged at 5,000 g for $30 \mathrm{~min}$ at $5^{\circ} \mathrm{C}$. The supernatant was filtered through Whatman No.1 paper, and the absorbance was measured by spectrophotometry (Optizen 2120 UV, Mecasys, Korea). The metmyoglobin $(\%)$ of the dry cured ham was acquired by the following formula (Krzywicki, 1979):

Metmyoglobin $(\%)=\{1.395-($ A572 - A700 $) /($ A525 $-\mathrm{A} 700)\} \times 100$

where A525 = absorbance at $525 \mathrm{~nm}$, A572= absorbance at $572 \mathrm{~nm}$ and $\mathrm{A} 700=$ absorbance at $700 \mathrm{~nm}$.

\section{Shear Force}

The Warner-Braztler test was conducted on the drycured ham, using the TA-XT2 $i$ texture analyzer (Stable Micro Systems, UK). The samples were prepared at approximately $1 \times 1 \times 2.5 \mathrm{~cm}$ (height $\times$ width $\times$ length), which was fixed in the muscle fiber direction. The shear force test was set up according to the method employed by Bermudez et al (2014); a shear blade with a triangular slot cutting edge ( $1 \mathrm{~mm}$ thickness) at a crosshead speed of $3.33 \mathrm{~mm} / \mathrm{s}$.

\section{Texture profile analysis}

A Texture Analyzer CT3 (Brookfield Engineering Laboratories, Inc., USA) was used to measure the texture profiles (hardness, springiness, cohesiveness, chewiness and gumminess), at room temperature, using a $25 \mathrm{~kg}$ load cell. The samples were kept for an hour at room temperature before conducting the texture analyses. A $6 \mathrm{~mm}$ diameter stainless plunger was used in the TPA tests. Duplicate cubes of $2.54 \times 2.54 \times 1.27 \mathrm{~cm}$ (length $\times$ width $\times$ height), which were cut out lengthwise from the fiber direction, were analyzed. The assay was done with the following conditions: The force-time curves were recorded at a crosshead speed of $1.0 \mathrm{~mm} / \mathrm{s}$ and the trigger force was $0.98 \mathrm{~N}$. The samples were compressed twice, to $40 \%$ of their original height, with an interval of $2 \mathrm{~s}$ between them. The values for hardness $(\mathrm{kg})$, springiness $(\mathrm{mm})$, cohesive- ness, gumminess $(\mathrm{kg})$ and chewiness $(\mathrm{mJ})$ were calculated by the results of the assay.

\section{Statistical analysis}

Statistical analyses of the data were conducted using SPSS 18.0. Data on the proximate compositions, the $\mathrm{pH}$, the water activity, the expressible drip, the color (lightness, redness and yellowness), the metmyoglobin, the TBARS value, the DPPH, the minerals, the proteolysis index and the texture parameters, were analyzed with a one-way analysis of variance (ANOVA), in which the diet was fixed as the main factor. A significant difference between the CON and $\mathrm{S}$ groups was analyzed using an independent $t$-test. All statistical tests of means were performed for a level of significance $(p<0.05)$. Correlations between all parameters were determined through correlation analyses, using the Pearson's linear correlation coefficient with SPSS 18.0.

\section{Results and Discussion}

\section{Effects of processed sulfur on physicochemical pro- perties, $\mathrm{pH}$, expressible drip and color of dry-cured ham}

The data on the physicochemical properties, the $\mathrm{pH}$, the expressible drip and the color of dry-cured ham is shown in Table 2. The moisture, crude protein and ash content between the $\mathrm{CON}$ and $\mathrm{S}$ groups did not show significant

Table 2. Physical characteristics and color of dry-cured ham from pig fed by diets supplemented with the processed sulfur

\begin{tabular}{ccccc}
\hline \hline & CON & S & SEM & $p$-value \\
\hline Moisture (\%) & 54.66 & 53.89 & 0.37 & 0.420 \\
Crude fat (\%) & $3.09^{\mathrm{a}}$ & $1.50^{\mathrm{b}}$ & 0.05 & $<0.001$ \\
Crude protein (\%) & 36.35 & 33.83 & 0.85 & 0.122 \\
Ash \%) & 9.07 & 8.50 & 0.20 & 0.191 \\
Total Collagen (g/kg) & $16.08^{\mathrm{b}}$ & $19.45^{\mathrm{a}}$ & 0.72 & 0.043 \\
Collagen solubility & $9.54^{\mathrm{b}}$ & $12.67^{\mathrm{a}}$ & 0.50 & 0.035 \\
(\% of total collagen) & & & & \\
Expressible drip (\%) & $35.69^{\mathrm{a}}$ & $31.61^{\mathrm{b}}$ & 0.92 & 0.020 \\
pH & $6.13^{\mathrm{b}}$ & $6.45^{\mathrm{a}}$ & 0.05 & 0.015 \\
$\mathrm{a}_{\mathrm{w}}$ & $0.902^{\mathrm{b}}$ & $0.912^{\mathrm{a}}$ & 0.001 & 0.017 \\
Total nitrogen & 5.82 & 5.41 & 0.14 & 0.152 \\
NPN $(\%)^{1)}$ & $0.39^{\mathrm{b}}$ & $0.52^{\mathrm{a}}$ & 0.02 & 0.005 \\
Proteolysis index (\%) & $6.72^{\mathrm{b}}$ & $9.67^{\mathrm{a}}$ & 0.25 & 0.002 \\
\hline Color & & & & \\
Lightness $\left(L^{*}\right)$ & $43.85^{\mathrm{a}}$ & $40.16^{\mathrm{b}}$ & 0.94 & 0.018 \\
Redness $\left(a^{*}\right)$ & 17.46 & 17.00 & 0.51 & 0.526 \\
Yellowness $\left(b^{*}\right)$ & 14.84 & 15.13 & 0.52 & 0.725 \\
\hline
\end{tabular}

SEM, standard error of the mean $(n=5) ; C O N$, control group; $\mathrm{S}$, $0.1 \%$ processed sulfur fed pigs. 
differences $(p>0.05)$, whereas the fat content of S group was significantly lower than that of CON group $(p<0.05)$. A reduction in the fat content in the meat of sulfur-fed pigs was reported by Kim et al. (2015). It has been confirmed that the inhibition of lipid accumulation was promoted through the inactivation of adipogenic genes by the intake sulfur compounds (Lee et al., 2011). The collagen content and collagen solubility of the $\mathrm{S}$ group were significantly higher than those of the CON $(p<0.05)$. Brown et al. (1965) reported that collagen synthesis was reduced by the limitation of dietary sulfur, due to the inhibition of fibroblast activity. Some scientists have indicated that the conversion ratio of collagen to soluble collagen increases under the absence of oxidative stress, and that this may improve meat texture (Archile-Contreras and Purslow, 2011; Archile-Contreras et al., 2011). A negative correlation was proved between the lipid oxidation and collagen solubility $(\mathrm{r}=-0.80, p<0.01)$. Also, the collagen solubility was increased in the meat due to the degradation of the protein throughout the ripening process (Cordoba et al., 1994).

The $\mathrm{pH}$ of the $\mathrm{S}$ group was found to be significantly higher than that of the CON $(p<0.05)$. According to Armau et al. (1995), the increasing $\mathrm{pH}$ of the dry-cured ham occurred as a result of the proteolysis during the aging period. This phenomenon was occurred by the accumulation of ammonia formation generated from protease activities (Virgili et al., 2007). Besides, the expressible drip of the $\mathrm{S}$ group was significantly lower than that of the CON group $(p<0.05)$. These results might be because the $\mathrm{pH}$ value of the meat is considered to be an important factor, in relation to the water holding capacity of meat, because of the establishment of a strong repulsive force to activate the water binding energy (Offer and Knight, 1988).

There was a no significant difference between both groups in regard to the total nitrogen content $(p>0.05)$. The NPN of the $\mathrm{S}$ group was significantly higher than that of $\mathrm{CON}(p<0.05)$, and the proteolysis index of the S group was also significantly higher than that of $\mathrm{CON}(p<0.05)$. Virgili et al. (2007) pronounced that NPN has positive relation with free amino acids during the ageing of dry cured ham. The proteolysis index is affected by various protease activities during the ripening period. The protease activities of dry-cured ham are influenced by a number of factors, such as additives, $\mathrm{pH}$, temperature and humidity conditions during the ripening period. Pogge et al. (2013) suggested that the protease activities of meat could be increased though the inhibition of lipid oxidation. The higher free amino acids content and oxidative stability of dry cured loin from processed sulfur fed pigs were reported compared with normal pigs by Kim et al. (2015b).

The lightness $\left(\mathrm{L}^{*}\right)$ of the dry-cured ham from the sulfur-fed pigs was significantly lower than that of the CON group $(p<0.05)$. However, there were no significant differences between the treatments in both the redness and yellowness $(p>0.05)$. Wilkins et al. reported that the $\mathrm{pH}$ has negative correlations with lightness and yellowness, and a negative correlation between the $\mathrm{pH}$ and the lightness was found in this study ( $\mathrm{r}=-0.72, p<0.01)$.

\section{Mineral status and proteolysis index of dry-cured ham}

Table 3 shows the mineral status and proteolysis index of the dry-cured ham. Both the calcium and iron content of the $\mathrm{S}$ group were significantly lower than that of the CON group $(p<0.001)$. The reduction of iron inhibited lipid oxidation due to the suppression of reacting with free radical in meat (Tang et al., 2000). Moreover, discoloration effect might be occurred because of binding with iron and myoglobin (Mitsumoto et al., 2005). Ferrous iron is converted to insoluble ferrous sulfide by a reaction with hydrogen sulfide, which is generated from sulfur compounds; this reaction retards the absorption of ferric iron in the intestine (Drewnoski et al., 2013; Ebrahimi et al., 2002; Magee et al., 2000).

A reduction in the $\mathrm{Ca}^{2+}$ content of meat from pigs fed methyl sulfonyl methane (MSM) was reported by Lee et al. (2009). Due to effect of the sulfur supplementation in the diet of the pigs, the increase in methionine and cystine promoted the excretion of calcium from the body (Song et al., 2013; Wang and Zhao, 1988). The formation of IP3 $\mathrm{R}$, which is used as a meat quality biomarker, was stimulated by the release of $\mathrm{Ca}^{2+}$, and an increase of IP3 R is found in low quality grade meat (Kim et al., 2008).

\section{Antioxidant potential and oxidative stability of dry- cured ham}

The DPPH free radical scavenging activity (\%) and oxidative stability of dry-cured ham were shown in Table 4. The DPPH free radical scavenging activity of the $\mathrm{S}$ group

Table 3. Mineral status of dry-cured ham from pig fed by diets supplemented with the processed sulfur

\begin{tabular}{lcccc}
\hline \hline & CON & S & SEM & $p$-value \\
\hline $\mathrm{Ca}, \mathrm{mg} / \mathrm{kg}$ & $258.56^{\mathrm{a}}$ & $144.31^{\mathrm{b}}$ & 0.16 & $<0.001$ \\
$\mathrm{Fe}, \mathrm{mg} / \mathrm{kg}$ & $7.97^{\mathrm{a}}$ & $4.12^{\mathrm{b}}$ & 0.06 & $<0.001$ \\
\hline
\end{tabular}

$\mathrm{SEM}$, standard error of the mean $(n=5) ; C O N$, control group; $\mathrm{S}$, $0.1 \%$ processed sulfur fed pigs; ${ }^{1)} \mathrm{NPN}$, non-protein nitrogen. 
Table 4. DPPH free radical scavenging activity, oxidative stability of dry-cured ham from pig fed by diets supplemented with the processed sulfur

\begin{tabular}{ccccc}
\hline \hline & CON & S & SEM & $p$-value \\
\hline DPPH free radical scavenging activity (\%) & $16.05^{\mathrm{b}}$ & $20.97^{\mathrm{a}}$ & 0.375 & 0.003 \\
TBARS $^{1)}$ & $0.35^{\mathrm{a}}$ & $0.26^{\mathrm{b}}$ & 0.02 & 0.010 \\
Metmyoglobin (\%) $^{\mathrm{b}}$ & $78.36^{\mathrm{a}}$ & $73.94^{\mathrm{b}}$ & 0.35 & $<0.001$ \\
\hline
\end{tabular}

SEM, standard error of the mean $(n=5)$; CON, control group; $S, 0.1 \%$ processed sulfur fed pigs.

${ }^{1)}$ TBARS units, MDA mg/kg.

was significantly higher than that of the CON group ( $p<$ 0.01 ). The antioxidant activities of the meat were enhanced because of the increasing protein hydrolysates, which had an ability to retard the lipid oxidation (Bougatef et al., 2009). In addition, Song et al. (2013) determined that feeding a high sulfur content diet affected the occurrence of sulfur-containing antioxidants such as methionine, cystein and glutathione. It is assumed that the $\mathrm{S}$ group is a possibility to maintain sulfur compounds of high rate, which the compounds have an excellent ability to act as efficient free radical scavengers. The TBA value (malondialdehyde $\mathrm{mg} / \mathrm{kg}$ ) of the S group showed a lower value than that of the CON group $(p<0.01)$. There was a positive correlation between the iron content and the TBA value in this study $(\mathrm{r}=0.90, p<0.01)$. Tang et al. (2000) suggested that lipid oxidation was induced by the accumulation of iron in chicken meat. The reduction of iron in meat could enhance the oxidative stability of dry-cured ham from processed sulfur-fed pigs. Besides, methionine and cysteine are reactive with hydroperoxide, generated from lipid peroxidation, due to the reducing power of the sulfur atom; the chain reaction of lipid oxidation is blocked by the formation of sulfoxide (Slump and Schreuder, 1973). Kim et al. (2014a) and Kim et al. (2014b) documented a lower TBA value of meat products from sulfur-fed pigs than in meat from basal diet-fed pigs.

The metmyoglobin (MetMb) of the $\mathrm{S}$ group was converted by a lower level when compared with the CON group $(p<0.001)$. The MetMb content is considered an important parameter of pigment oxidation, and several factors could manipulate pigment oxidation, such as preservation treatments, cooking process, fat content, $\mathrm{pH}$ and package methods (King and Whyte, 2006). Furthermore, the primary and secondary products that are decomposed from lipid oxidation stimulate pigment oxidation; pigment oxidation has a positive correlation with lipid oxidation (Faustman et al., 2010). The positive correlation between the TBARS and the metmyoglobin content was determined $(\mathrm{r}=0.88, p<0.01)$. On the other hand, the metmyoglobin concentration in beef with sulfur supplementation was lower than that of beef with Vitamin E sup- plementation, although the degree of lipid oxidation in beef with sulfur supplementation showed an increase compared to beef with Vitamin E supplementation (Lee et al., 2008). In addition, studies by Warriss (2000) showed that the oxidation of the myoglobin to MetMb tends to be promoted at a lower $\mathrm{pH}$. These results may have occurred, since the decrease in iron concentration affects the meat color.

\section{Texture profile analysis (TPA)}

The TPA parameters of dry-cured ham from the nonprocessed sulfur-fed pigs, and processed sulfur-fed pigs, are shown in Table 5. The dry-cured ham from pigs treated with processed sulfur maintained some tendency toward a lower shear force than the control $(p<0.1)$. The shear force has a negative correlation with the proteolysis index and the collagen solubility $(\mathrm{r}=-0.83$ and $\mathrm{r}=-0,95, p<0.01)$. Likewise, gumminess and cohesiveness of dry-cured ham from processed sulfur-fed pigs showed a tendency to be lower compared to the control group $(p<0.1)$. According to Lorenzo et al. (2014), the water activity had negative correlations with both the gumminess and the cohesiveness. In this study, the water activity and the gumminess had a negative correlation $(\mathrm{r}=-0.66, p<0.05)$. The springiness of dry-cured ham from processed sulfur-fed pigs was significantly lower than that of the CON group $(p<0.05)$. No significant differences regarding the hardness and chewiness of dry-cured ham, due to the dietary supplementation of processed sulfur, were observed in this study $(p>$

Table 5. The textural attributes of dry-cured ham from pig fed by diets supplemented with the processed sulfur sulfur (S) supplemented diets from weaning to fattening phase

\begin{tabular}{ccccc}
\hline \hline Parameters & CON & S & SEM & $p$-value \\
\hline Shear force $(\mathrm{kg})$ & 5.25 & 4.51 & 0.18 & 0.07 \\
Hardness $(\mathrm{kg})$ & 8.41 & 7.62 & 1.02 & 0.62 \\
Springiness $(\mathrm{mm})$ & 5.70 & 4.85 & 0.18 & 0.03 \\
Cohesiveness & 0.43 & 0.39 & 0.01 & 0.10 \\
Gumminess $(\mathrm{kg})$ & 3.19 & 1.84 & 0.36 & 0.09 \\
Chewiness $(\mathrm{mJ})$ & 164.47 & 155.17 & 6.87 & 0.39 \\
\hline
\end{tabular}

SEM, standard error of the mean $(n=5)$; CON, control group; $\mathrm{S}$, $0.1 \%$ processed sulfur fed pigs. 
Table 6. Pearson correlations among metmyoglobin (Metmb), TBARS, color (lightness, redness and yellowness), collagen solubility (CS), proteolysis index (PI), minerals and texture profile

\begin{tabular}{ccccccccccccccc}
\hline \hline & TBARS & $\mathrm{L}^{*}$ & $\mathrm{a}^{*}$ & $\mathrm{~b}^{*}$ & $\mathrm{CS}$ & PI & HS & CHS & SPG & GM & CWN & SF & Iron & Calcium \\
\hline Metmb & $0.88^{* *}$ & $-0.63^{* *}$ & 0.023 & -0.31 & $-0.84^{* *}$ & $-0.92^{* *}$ & 0.52 & 0.41 & 0.35 & $0.74^{* *}$ & -0.89 & $0.77^{* *}$ & $0.95^{* *}$ & $0.95^{* *}$ \\
TBARS & 1 & $-0.57^{*}$ & 0.08 & -0.11 & $-0.80^{* *}$ & $-0.89^{* *}$ & 0.48 & 0.31 & 0.41 & 0.63 & 0.12 & $0.76^{* *}$ & $0.92^{* *}$ & $0.93^{* *}$ \\
L $^{*}$ & & 1 & 0.06 & $0.66^{* *}$ & 0.33 & -0.59 & -0.55 & -0.24 & -0.17 & $-0.70^{*}$ & 0.81 & -0.33 & $-0.53^{*}$ & $-0.54^{*}$ \\
$\mathrm{a}^{*}$ & & & 1 & 0.37 & -0.13 & -0.22 & 0.03 & 0.12 & 0.28 & 0.05 & 0.37 & -0.22 & 0.16 & 0.17 \\
$\mathrm{~b}^{*}$ & & & & 1 & 0.02 & 0.11 & -0.19 & -0.20 & 0.35 & -0.35 & $0.99^{*}$ & -0.12 & -0.06 & -0.07 \\
CS & & & & & 1 & $0.88^{* *}$ & -0.52 & -0.08 & $-0.60^{*}$ & -0.54 & -0.12 & $-0.95^{* *}$ & $-0.90^{* *}$ & $-0.90^{* *}$ \\
PI & & & & & & 1 & -0.37 & -0.32 & -0.43 & -0.52 & 0.12 & $-0.83^{* *}$ & $-0.97^{* *}$ & $-0.97^{* *}$ \\
HS & & & & & & 1 & -0.33 & $0.67^{*}$ & $0.87^{* *}$ & -0.37 & 0.44 & 0.50 & 0.50 \\
CHS & & & & & & & 1 & -0.56 & 0.17 & -0.82 & 0.13 & 0.26 & 0.26 \\
SPG & & & & & & & & 1 & 0.36 & 0.96 & 0.58 & 0.51 & 0.51 \\
GM & & & & & & & & & 1 & -0.93 & 0.48 & $0.62^{*}$ & $0.62^{*}$ \\
CWN & & & & & & & & & & & 1 & 0.12 & 0.12 & 0.12 \\
SF & & & & & & & & & & & & 1 & $0.80^{* *}$ & $0.80^{* *}$ \\
\hline
\end{tabular}

Only significant correlations are shown. ${ }^{*} p<0.05,{ }^{* *} p<0.01,{ }^{* * *} p<0.001$.

0.05). According to Bailey and Light (1989), muscles with high collagen content showed a lower compressive-force value than that of other muscles with low collagen content. However, no correlations between the collagen content and the texture parameters were shown in this study.

Relationship between metmyoglobin (Metmb), TBARS, color (lightness, redness and yellowness), collagen solubility (CS), proteolysis index (PI) and texture profile

Pearson's correlations among the variables studied are expressed in Table 6 . The iron content has highly positive correlations with the Metmb and the TBARS ( $\mathrm{r}=0.95, p<$ $0.01 ; \mathrm{r}=0.92, p<0.01)$. Meanwhile, the lipid oxidation has negative correlations with both the collagen solubility and the proteolysis index $(\mathrm{r}=-0.80, p<0.01 ; \mathrm{r}=-0.90, p<0.01)$. In addition, a positive correlation between the collagen solubility and the proteolysis index was shown ( $\mathrm{r}=0.88, p$ $<0.01$ ), and both the CS and the PI have negative correlations with shear force $(\mathrm{r}=-0.95, p<0.01 ; \mathrm{r}=-0.83, p<0.01)$.

\section{Conclusion}

The results of this study suggest that supplementation with processed sulfur increases the antioxidant ability, the $\mathrm{pH}$, the expressible drip, the lightness and the texture attributes in dry-cured ham. We also found that the collagen solubility was increased in dry-cured ham from pigs supplemented with processed sulfur. Additionally, the lower shear force and higher proteolysis index of dry cured ham from processed sulfur-fed pigs were proven, compared to the basal diet-fed pigs. In conclusion, the feeding of $0.1 \%$ processed sulfur to pigs, used for the production of high dry-cured ham quality and to reduce the ripening period during manufacturing.

\section{Acknowledgements}

This research was supported by the Technology Commercialization Support Program, iPET (Korea Institute of Planning and Evaluation for Technology in Food, Agriculture, Forestry and Fisheries), Ministry of Agriculture, Food and Rural Affairs, the Republic of Korea.

\section{References}

1. Andres, A. I., Cava, R., Ventanas, J., Muriel, E., and Ruiz, J. (2004) Lipid oxidative changes throughout the ripening of dry-cured Iberian hams with different salt contents and processing conditions. Food Chem. 84, 375-381.

2. AOAC (1995) Official methods of analysis of AOAC. 17th Ed. Association of Official Analytical Chemists. Washington D.C.

3. Archile-Contreras, A. C., Cha, M. C., Mandell, I. B., Miller, S. P., and Purslow, P. P. (2011) Vitamins E and C may increase collagen turnover by intramuscular fibroblasts. Potential for improved meat quality. J. Agric. Food Chem. 59, 608-614.

4. Archile-Contreras, A. C. and Purslow, P. P. (2011) Oxidative stress affect meat quality by interfering with collagen turnover by muscle fibroblasts. Food Res. Int.44, 582-588.

5. Aranu, J., Gou, P., and Comaposada, J. (2003) Effect of the relative humidity of drying air during the resting period on the composition and appearance of dry-cured ham surface. Meat Sci. 65, 1275-1280.

6. Arnau, J., Guerrero, L., Casademont, G., and Gou, P. (1995) Physical and chemical changes in different zones of normal and PSE dry cured ham during processing. Food Chem. 52, 63-69.

7. Bailey, A. J. and Light, N. D. (1989) Connective tissue in meat 
and meat products. Elsevier Applied Science, London.

8. Bermudez, R., France, D., Carballo, J., and Lorenzo, J. M. (2014) Physicochemical changes during manufacture and final sensory characteristics of dry-cured celta ham. Effect of muscle type. Food Control 43, 263-269.

9. Bougatef, A., Hajji, M., Balti, R., Lassoued, I., Triki-Ellouz, Y., and Nasri, M. (2009) Antioxidant and free radical-scavenging activities of smooth hound (Mustelus mustelus) muscle protein hydrolysates obtained by gastrointestinal proteases. Food Chem. 114, 1198-1205.

10. Brosnan, J. T. and Brosnan, M. E. (2006) The sulfur-containing amino acids: An overview. J. Nutr. 136, 16365-16405.

11. Brown, R. G., Button, G. M., and Smith, J. T. (1965) Changes in collagen metabolism caused by feeding diets low in inorganic sulfur. J. Nutr. 87, 228-232.

12. Careri, M., Mangia, A., Barbieri, G., Bolzoni, L., Virgili, R. and Parolari, G. (1993) Sensory property relationships to chemical data of Italian-type dry-cured ham. J. Food Sci. 58, 968-972.

13. Cho, J. H., Min, B. J., Kwon, O. S., Shon, K. S., Jin, Y. G., Kim, H. J., and Kim I. H. (2005) Effects of MSM (methyl sulfonyl methane) supplementation on growth performance and digestibility of $\mathrm{Ca}$ and $\mathrm{N}$ in pigs. J. Korean Soc. Food Sci. Nutr. 34, 361- 365.

14. Cordoba, J. J., Antequera, T., Ventanas, J., Lopez-Bote, C., Garcia, C., and Asensio, M. A. (1994) Hydrolysis and loss of extractability of proteins during ripening of Iberian ham. Meat Sci. 37,217-227.

15. Drewnoski, M. E., Doane, P., and Hansen, L. (2013) Ferric citrate decreases ruminal hydrogen sulphide concentrations in feedlot cattle fed diets high in sulphate. Br. J. Nutr. 111, 261-269.

16. Drewnoski, M. E., Pogge, D. J., and Hansen, S. L. (2014) Highsulfur in beef cattle diets: A review. J. Anim. Sci. 92, 37633780

17. Ebrahimi, S., Kleerebezem, R., van Loosdrecht, M. C. M., and Heijen, J. J. (2002) Kinetics of the reactive absorption of hydrogen sulfide into aqueous ferric sulfate solutions. Chem. Eng. Sci. 58, 417-427.

18. Faustman, C., Sun, Q., Mancini, R., and Suman, S. P. (2010) Myoglobin and lipid oxidation interactions: Mechanistic bases and control. Meat Sci. 86, 86-94.

19. Jang, H. D., Yoo, J. S., Chae, S. J., Park, S. L., Kim, I. C., Park, J. C., Jung, H. J., Kim, Y. H., Kim, I. H., and Seok, H. B. (2006) Effects of dietary of methyl sulfonyl methane on growth performance and meat quality characteristics in growing-finishing pigs. Korean J. Intl. Agri. 18, 116-120.

20. Kim, J. H., Lee, H. R., Pyun, C. W., Kim, S. K., and Lee, C. H. (2014a) Changes in physicochemical, microbiological and sensory properties of dry-cured ham in processed sulfur fed pigs. J. Food Process. Pres. doi:10.1111/jfpp.12293

21. Kim, J. H., Pyun, C. W., Hong, G. E., Kim, S. K., Yang, C Y., and Lee, C. H. (2014b) Changes in physicochemical and microbiological properties of isoflavone-treated dry-cured sausage from sulfur-fed pork during storage. J. Anim. Sci. Tech. 56, $2-7$.
22. Kim, J. H., Noh, H. Y., Kim, G. H., Hong, G. E., Kim, S. K., and Lee, C. H. (2015a) Effect of dietary supplementation with processed sulfur on meat quality and oxidative stability in longissimus dorsi of pigs. Korean J. Food Sci. An. 35, 330338.

23. Kim, J. H., Hong, G. E., Pyun, C. W., Park, W. J., and Lee C. H. (2015b) Enhancement of physicochemical, microbiological and sensory properties of dry cured loin by using processed sulfur fed pigs. Anim. Prod. Sci. http://dx.doi.drg/ 10.1071/AN14680

24. Kim, N. K., Cho, S., Lee, S. H., Park, H. R., Lee, C. S., Cho, Y. M., Choy, Y. H., Yoon, D., Im, S. K., and Park, E. W. (2008) Proteins in longissimus muscle of Korean native cattle and their relationship to meat quality. Meat Sci. 80, 10681073.

25. King, N. J. and Whyte, R. (2006) Does it look cooked? A review of factors that influence cooked meat color. J. Food Sci. 71, R31- R40.

26. Krzywicki, K. (1979) Assessment of relative content of myoglobin, oxymyoglobin and metmyoglobin at the surface of beef. Meat Sci. 3, 1-5.

27. Lee, J. I., Min, H. K., Lee, J. W., Jeong, J. D., Ha, Y. J., Kwack, S. C., and Park, J. S. (2009) Changes in the quality of loin from pigs supplemented with dietary methyl sulfonyl methane during cold storage. Korean J. Food Sci. Ani. Resour. 29, 229-237.

28. Lee, M. S., Kim, I. H., Kim, C. T., and Kim, Y. (2011) Reduction of body weight by dietary garlic is associated with an increase in uncoupling protein mRNA expression and activiation of AMP-activated protein kinase in diet-induced obese mince $^{1-3}$. J. Nutr. 141, 1847-1953.

29. Lee, S. K., Panjono, Kang, S. M., Kim, T. S., and Park, Y. S. (2008) The effects of dietary sulfur and vitamin E supplementation on the quality of beef from the longissimus muscle of hanwoo bulls. Asian-Aust. J. Anim. Sci. 21, 1059-1066.

30. Lorenzo, J. M. (2014) Changes on physic-chemical, textural, lipolysis and volatile compounds during the manufacture of dry-cured foal "cecina”. Meat Sci. 96, 256-263.

31. Lundstrom, K., Essen-Gustavsson, B., Rundgren, M., Edforslilja, L., and Malmfors, G. (1989) Effect of halothane genotype on muscle metabolism at slaughter and its relationship with meat quality- a within-litter comparison. Meat Sci. 25, 251-263.

32. Magee, E. A., Richardson, C. J., Hughes, R., and Cummings, J. H. (2000) Contribution of dietary protein to sulfide production in the large intestine: an in vitro and a controlled feeding study in humans. Am. J. Clin. Nutr. 72, 1488-1494.

33. Mitsumoto, M., O'Grady, M. N., Kerry, J. P., and Buckley, D. J. (2005) Addition of tea catechins and vitamin C on sensory evaluation, colour and lipid stability during chilled storage in cooked or raw beef and chicken patties. Meat Sci. 69, 773779.

34. Moran, L., Andres, S., Bodas, R., Prieto, N., and Javier Giraldez, F. (2012) Meat texture and antioxidant status are improved when carnosic acid is included in the diet of fattening lambs. Meat Sci. 91, 430-434. 
35. National Research Council (NRC) (1998). Nutrients Requirements of Swine. $9^{\text {th }}$ ed. National Academic Press, Washington, DC.

36. Nishimura, T. (2010) The role of intramuscular connective tissue in meat texture. Anim. Sci. J. 81, 21-27.

37. Offer, G. and Knight, P. (1988) The structural basis of waterholding capacity in meat. Part 2: Drip losses. In: Developments in meat science. Lawrie, R. (ed), Elsevier Science, London, Vol. 4, pp. 173-243.

38. Overland, M., Borge, G. I., Vogt, G., Schoyen, H. F., and Skrede, A. (2011) Oxidative stability and sensory quality of meat from broiler chickens fed a bacterial meal produced on natural gas. Poult. Sci. 90, 201-210.

39. Pogge, D. J., Lonergan, S. M., and Hansen, S. L. (2013) Supplemental vitamin $\mathrm{C}$ alleviates the negative effect of high sulfur on meat quality. Animal Industry Report, AS 659, ASL R2766.

40. Rossi, R., Pastorelli, G., Cannata, S., Tavaniello, S., Maiorano, G., and Corino, C. (2013) Effect of long term dietary supplementation with plant extract on carcass characteristics meat quality and oxidative stability in pork. Meat Sci. 95, 542548.

41. Schilling, M. W., Mink, L. E., Gochenour, P. S., Marriott, N. G., and Alvarado, C. Z. (2003) Utilization of pork collagen for functionality improvement of boneless cured ham manufactured from pale, soft, and exudative pork. Meat Sci. 65 , 547-553.

42. Slump, P. and Schreuder, H. A. W. (1973) Oxidation of methionine and cysteine in foods treated with hydrogen peroxide. J. Sci. Food Agric. 24, 657-661.

43. Song, R., Chen, C., Wang, L., Johnston, J., Kerr, B. J., Weber, T. E., and Shurson, G. C. (2013) High sulfur content in corn dried distillers grains with soluble protects against oxidized lipids by increasing sulfur-containing antioxidants in nursery pigs. J. Anim. Sci. 91, 2715-2728.

44. Tang, S. Z., Kerry, J. P., Sheehan, D., Buckley, D. J., and Morrissey, P. A. (2000) Dietary tea catechins and iron-induced lipid oxidation in chicken meat, liver and heart. Meat Sci. 56, 285-290.

45. Tejerina, D., Garcia-Torres, S., Caveza de Vaca, M., Vazquez, F. M., and Cava, R. (2011) Acorns (Quercus rotundiflolia Lam) and grass as natural sources of antioxidants and fatty acids in the "montanera" feeding of Iberian pigs: Intra- and inter- annual variation. Food Chem. 124, 997-1004.

46. Toldra, F. and Flores, M. (1998) The role of muscle proteases and lipases in flavor development during the processing of dry-cured ham. Crit. Rev. Food Sci. 38, 331-352.

47. Ventanas, S., Ventanas, J., Tovar, J., Garcia, C., and Estevez, M. (2007) Extensive feeding versus oleic acid and tocopherol enriched mixed diets for the production of Iberian dry-cured hams: Effect on chemical composition, oxidative status and sensory traits. Meat Sci. 77, 246-256.

48. Virgili, R., Saccani, G., Gabba, L., Tanzi, E., and Bordini, C. S. (2007) Changes of free amino acids and biogenic amines during extended ageing of Italian dry-cured ham. LWT- Food Sci. Technol. 40, 871-878.

49. Wang, X. B. and Zhao, X. H. (1988) The effect of dietary sulfur-containing amino acids on calcium excretion. $A d v$. Exp. Med. Biol. 442, 495-499.

50. Warriss, P. (2000) Meat Science: an introductory text. Oxon: CABI publishing. p. 310.

51. Witte, V. C., Krause, G. F., and Bailey, M. E. (1970) A new extraction method for determining 2- thiobarbituric acid values of pork and beef during storage. J. Food Sci. 35, 582585. 